\title{
PENGEMBANGAN MODUL FILSAFAT BAHASA SCIENTIFIC BERBASIS NILAI KEARIFAN LOKAL
}

\author{
Sugeng Suryanto dan Agoes Hendriyanto \\ STKIP PGRI Pacitan \\ email: rafid.musyffa@gmail.com
}

\begin{abstract}
Abstrak
Penelitian ini bertujuan mengembangkan modul filsafat bahasa scientific berbasis nilai kearifan lokal dan filsafat bahas a kekinian. Dari validasi ahli diperoleh nilai sebesar $89 \%$ dengan kategori sangat layak, sedangkan hasil perhitungan angket respons mahasiswa diperoleh nilai sebesar 88,6\% dengan kategori sangat layak. Setelah direvisi dilakukan uji coba secara terbatas menggunakan metode eksperimen single one shot case study dan uji coba secara luas menggunakan eksperimen one group pretest-posttest. Berdasarkan hasil uji coba terbatas disimpulkan bahwa modul dikembangkan layak digunakan untuk kegiatan pembelajaran pada mata kuliah filsafat bahasa di Jurusan Bahasa dan Sastra Indonesia STKIP PGRI Pacitan. Selanjutnya, berdasarkan hasil uji coba pemakaian secara luasdisimpulkan bahwa modul yang dikembangkan dapat digunakan untuk kegiatan pembelajaran pada mata kuliah filsafat bahasa di Jurusan Bahasa dan Sastra Indonesia Perguruan Tinggi.
\end{abstract}

Kata kunci: filsafat bahasa, scientific, kearifan lokal, dan modul

\section{DEVELOPING A MODULE OF SCIENTIFIC LANGUAGE PHILOSOPHY BASED ON LOCAL WISDOM VALUES}

\begin{abstract}
This study aims to develop a module of scientific language philosophy based on local wisdom values and contemporary language philosophy. From the expert validation, a score of $89 \%$ was obtained, indicating that the module was very appropriate. Meanwhile, a score of $88.6 \%$ was obtained from the students' responses, indicating that the module was appropriate. After a revision, a small-scale tryout was conducted through an experiment using the single one shot case study design and a large-scale tryout through an experiment using the one group pretest-posttest design. Based on the results of the small-scale tryout, it is concluded that the developed module is appropriate for learning activities in philosophy of language at the Department of Indonesian Language and Literature, STKIP PGRI Pacitan. Further, based on the results of the large-scale tryout, it is concluded that the developed module can be used in learning activities in philosophy of language at the Department of Indonesian Language and Literature in higher education.
\end{abstract}

Keywords: philosophy of language, scientific, local wisdom, module

\section{PENDAHULUAN}

Pengajaran di perguruan tinggi banyak mengalami beberapa hambatan yang perlu sekali dipecahkan bersama. Globalisasi membawa perubahan daya pikir mahasiswa yang pragmatik dan materialisme. Mahasiswa lebih menyukai hal-hal yang berhubungan dengan peralatan baru seperti smartphone dan mengerjakan tugas sebagai menggugurkan kewajiban 
sebagai mahasiswa tidak melalui proses yang baik.

Kompetensi dosen harus senantiasa ditingkatkan dengan berbagai bentuk kegiatan seperti; pelatihan, workshop, seminar, penelitian dan pengabdian masyarakat sesuai dengan bidang ilmunya. Peningkatan kompetensi diharapkan dapat membuat suatu pembelajaran di kelas menyenangkan sehingga mahasiswa termotivasi dalam mengikuti perkuliahan tidak hanya absen dan nilai semata. Pembelajaran harus direncanakan dan diarahkan untuk membentuk manusia yang cerdas, mandiri, kreatif dalam rangka menghadapi tantangan jaman.

Mahasiswa diharapkan semakin kritis terhadap materi yang diajarkan dosen. Dosen diharuskan mempersiapkan materi yang menarik yang berhubungan dengan persoalan kehidupan. Hubungan komunikasi dua arah diharapkan dalam setiap proses perkuliahan di kelas. Materi yang diajarkan dosen harus mencakup kompetensi yang berhubungan dengan: hakikat pengetahuan, cara mendapatkan pengetahuan melalui metode penelitian, serta aspek nilai yang harus menjadi dasar berpikir mahasiswa. Hakikat sebuah ilmu mahasiswa harus memperbanyak membaca buku filsafat bahasa sebagai salah satu cara untuk mendapatkan pengetahuan dan pengalaman. Metode kajian untuk menyelesaikan pertanyaan diselesaikan dengan pendekatan scientific. Selanjutnya nilai, moral yang bersumber dari nilai kearifan lokal sebagai dasar dalam berpikir untuk menghasilkan sebuah jawaban dari pertanyaan atau permasalahan

Latar belakang mahasiswa yang berasal dari berbagai daerah dengan berbagai latar belakang sosial, budaya, menyebabkan perbedaan pemikiran. Keberagaman tersebut harus dapat dijadikan sebagai kekayaan berpikir mahasiswa. Keberagaman dapat dijadikan kekuatan untuk pertimbangan dalam menganalisis sebuah persoalan. Sehingga akan menghasilkan pemikiran kritis yang mempunyai nilai kebermaknaan baik bagi mahasiswa maupun orang lain. Sebaliknya keberagaman tersebut akan meningkatkan kemampuan berpikir kritis mahasiswa. Kemampuan berpikir tersebut senantiasa dilandasi oleh fakta nyata dikaji menggunakan teori dengan menggunakan metode tertentu yang didasari nilai kearifan lokal.

Zaman modern sekarang setiap pendidikan menjadi terancam bahaya, menjadi berat sebelah, segala perhatian tertuju pada pertumbuhan ekonomi. Globalisasi menjadi pendorong bagi perkembangan paham pragmatisme, materialisme dan hedonisme. Manusia mempunyai kecenderungan untuk mendapatkan sesuatu yang diinginkan tanpa berusaha dengan maksimal yang menjadi budaya sekarang ini. Maraknya kasus korupsi yang tidak ada habis-habisnya diberitakan di media televisi atau media lainnya menjadi faktor penghambat bagi kemajun bangsa dan negara. Nilai kearifan lokal akan semakin terdesak keberadaannya di tengah masyarakat. Mahasiswa sebagai generasi penerus bangsa jangan hanya menjadikan kearifan lokal sebuah pusaka yang hanya sebagai pajangan dan tontonan. Mahasiswa harus mendapatkan materi tersebut di bangku kuliah sehingga dapat membuat sebuah kegiatan yang inovatif bagi kelangsungan nilai kearifan lokal di masyarakat. Nilai tersebut sebenarnya dapat langsung dipraktekan mahasiswa dalam hubungannya dengan lingkungan dalam kampus.

Materi perkuliahan yang disusun oleh dosen harus memasukan unsur nilai kearifan lokal sebagai bagian dari axiologi atau nilai dari sebuah mata kuliah. Nilai tersebut yang paling efektif disusun dalam bentuk modul dengan memadukan epistemologi dan ontologi sebuah mata kuliah. Dengan demikian modul tersebut terdapat hakikat sebuah ilmu pengetahuan, metode keilmuwan, dan nilai atau moral dalam menghasilkan sebuah ilmu 
pengetahuan. Nilai kegunaan sebuah ilmu akan bermanfaat bagi masyarakat jika mengandung ketiga aspek tersebut. Oleh karena itu, materi perkuliahan harus selalu menampilkan epistemologi, ontologi, dan axiologi sebuah ilmu pengetahuan khususnya bahasa untuk menghasilkan calon ilmuwan, teknokrat, pemimpin yang unggul. Tanpa membekali mahasiswa dengan nilai atau axiologi sebuah ilmu bahasa maka perguruan tinggi akan melahirkan ilmuwan-ilmuwan, teknolog yang pintar tanpa mempunyai hati nurani.

Perguruan tinggi sebagai lembaga pendidikan yang mencetak calon teknokrat, birikrat, pemimpin, ahli hukum dan profesi lainnya mempunyai tanggung jawab yang besar bagi lahirnya manusia yang unggul. Salah satu yang dapat dilakukan oleh perguruan tinggi dengan melakukan perubahan kebijakan untuk mewujudkan harapan tersebut. Namun kendala dilapangan belum siapnya sumber daya yang mendukung memerlukan sebuah penyesuaian bagi lembaga pendidikan tinggi baik di kota maupun di pelosok daerah di Indonesia. Peningkatan kompetensi dosen baik kognitif, afektif, maupun psikomotorik sangat diharapkan untuk meningkatkan kualitas lulusan yang dihasilkan. Kompetensi profesional, pedagogik, dan sosial dosen harus terus ditingkatkan untuk menghadapi perubahan kebudayaan khususnya mahasiswa yang akan menjadi sarjana. Peran dosen sangat besar sekali dalam pelaksanaan kurikulum berbasis KKNI dengan melakukan inovasi pembelajaran yang disesuaikan dengan kompetensi yang ingin dicapai. Setiap pembelajaran di kelas dosen harus menyusun rencana pembelajaran semester yang harus mencatumkan kompetensi kognitif, afektif, dan psikomotorik. Kompetensi yang tersebut di atas harus selalu menjadi indikator dalam pencapaian tujuan pembelajaran setiap mata kuliah.
Matakuliah filsafat bahasa merupakan mata kuliah yang mengajarkan mahasiswa untuk mengkaji persoalan secara mendalam berdasarkan analisis data, fakta, dan pendapat ahli yang akan diwujudkan dalam bentuk jawaban baik secara tulisan maupun lisan. Kompetensi berbahasa sangat diharapkan dapat tercapai dengan menggunakan modul mata kuliah filsafat bahasa. Modul yang ada tidak dapat diterapkan kepada mahasiswa perlu adanya pengembangan disesuaikan dengan perkembangan kemajuan ilmu pengetahuan khususnya ilmu bahasa.

Implementasi kompetensi disesuaikan dengan materi dan tingkat kebutuhan dan kesiapan mahasiswa. Kompetensi tersebut tidak bisa kita paksakan dalam setiap materi perkulihan di kelas. Minimal kompetensi tersebut setidaknya meliputi aspek; kognitif, afektif, dan psikomotorik harus ditulis dalam setiap awal materi baru. Salah satu yang dapat dilakukan oleh dosen dengan membuat modul mata kuliah yang didalamnya tercantum kompetensi yang harus dicapai harus sesuai dengan materi. Perencanaan ini dapat memudahkan dosen dan mahasiswa untuk mencapai target peningkatan kemampuan berpikir kritis mahasiswa dengan pendekatan scientific berbasis nilai kearifan lokal.

Profesionalisme dosen dalam proses pembelajaran di kelas sangat diharapkan demi pencapaian kompetensi yang telah dirumuskan pada setiap pendahuluan modul. Pembelajaran dengan menggunakan modul harus disesuaikan dengan kondisi kekinian. Pengembangan modul sangat perlu, disebabkan semakin cepatnya perubahan dalam dunia pendidikan terutama dalam bidang teknologi pembelajaran. Perubahan yang sangat cepat memerlukan kajian yang mendalam terhadap mata kuliah yang disesuaikan dengan kondisi kekinian.

Selain yang telah diuraikan di atas pengembangan modul harus didasarkan 
dengan KKNI. Jenjang strata 1 (S1) harus dapat mengimplementasikan 6 level KKNI dalam modul. Adapun 6 level tersebut meliputi: 1) level pertama, mahasiswa harus menguasai pengetahuan faktual; 2) level kedua, mahasiswa harus menguasai pengetahuan operasional dasar dan pengetahuan fatual; 3) level ketiga, mahasiswa harus menguasai konsep umum pengetahuan dan operasional lengkap; 4) level keempat, mahasiswa harus menguasai prinsip dasar pengetahuan dan keterampilan; 5) level kelima, mahasiswa harus menguasai konsep teoritis bidang pengetahun dan keterampilan; dan 6) level keenam, mahasiswa harus menguasai konsep teoritis bidang pengetahuan dan keterampilan tertentu secara umum dan konsep teoritis bidang pengetahuan dan keterampilan secara umum.

KKNI tersebut harus selalu diadopsi dalam setiap kompetensi dalam setiap pengembangan modul khususnya mata kuliah di perguruan tinggi. Modul harus mencantumkan kegiatan pembeajaran yang inovatif dan kreatif yang berpusat pada mahasiswa sehingga dosen berperan sebagai fasilitator di kelas. Pembelajaran yang menarik merupakan pembelajaran yang berusaha untuk memanfaatkan setiap komponen pembelajaran yang meliputi mahasiswa, dosen, serta media pembelajaran. Media pembelajaran salah satuya dengan mengembangkan modul disesuaikan dengan kondisi kekinian. Kreatifitas dosen dalam mengembangkan modul pembelajaran sangat dibutuhkan dalam rangka menyesuaikan konsep atau teori yang telah berkembang saat ini dengan kondisi kekinian mahasiswa.

Pengembangan modul juga harus mengadopsi 4 pilar dari International Bureau of Education (IBE Unesco) dalam kompetensi modul dan penyusunan materi. Adapun 4 pilar yang terdapat dalam IBE Unesco meliputi: 1) Learning to know(think), 2) Learning to do (learn), 3) Learning to be, dan
4) Learning to live together. Pengembangan modul dengan berdasarkan pada 4 pilar di atas memungkinkan dilakukan pada mata kuliah filsafat bahasa. Materi yang ada dalam filsafat bahasa selalu menggunakan tahapan berpikir scientific seperti yang diamanatkan dalam IBE Unesco. Tahapan pemikiran filsafat bahasa selalu diawali adanya sebuah pengamatan terhadap sebuah objek nyata. Selanjutnya akan menemukan sebuah permasalahan yang digunaakan sebagai dasar untuk memilih metode penelitian untuk mendapatkan data baik yang bersifat kualitatif maupun kuantitatif. Proses selanjutnya verifikasi dan validitas data yang telah terkumpul yang akan digunakan untuk analisis permasalahan yang telah dirumuskan di awal kegiatan. Proses selanjutnya analisis data dengan berdasarkan teori atau konsep untuk mendapatkan jawaban terhadap rumusan masalah.

Untuk itu peneliti tertarik untuk mengembangkan modul filsafat bahasa dengan scientific berbasis nilai kearifan lokal yang sesuai dengan amanat dalam KKNI dan IBE Unesco. Matakuliah filsafat bahasa akan menjadi pendorong bagi perubahan sikap mahasiswa untuk berpikir kritis dengan menggunakan pemikiran secara ilmiah (scientific) berasarkan nilai kearifan lokal. Filsafat bahasa sebagai ilmu yang memanusiakan manusia diharapkan dapat mempersiapkan mahasiswa untuk berpikiran kritis. Pemikiran kritis sangat diperlukan untuk berkomunikasi dengan sesama manusia, berkomunikasi dengan Tuhan Yang Maha Pencipta, dan berkomunikasi dengan alam semesta. Pengembangan modul filsafat bahasa haru melalui metode penelitian pengembangan dengan beberapa tahapan yang harus dilalui untuk menghasilkan modul filsafat bahasa yang layak dan efektif digunakan untuk kegiatan pembelajaran filsafat bahasa di Perguruan Tinggi. 


\section{METODE}

Penelitian ini menggunakan metode penelitian pengembangan $\mathrm{R} \& \mathrm{D}$ (Research and Development). Penelitian pengembangan ini bertujuan untuk menghasilkan modul "Filsafat bahasa" yang layak digunakan untuk meningkatkan kemempuan berpikir kritis mahasiswa khususnya berkaitan dengan kompetensi berbahasa. Sejalan dengan tujuan tersebut desain penelitian yang digunakan desain penelitian pengembangan. Desain penelitian pengembangan ini dirancang untuk menghasilkan 2 produk yang berupa modul; filsafat bahasa scientific berbasis nilai kearifan lokal dan filsafat bahasa kekinian.

Sugiyono (2011: 298) penelitian pengembangan menggunakan prosedur atau langkah-langkah sebagai berikut: (1) potensi dan masalah, (2) pengumpulan data, (3) desain produk, (4) validasi desain, (5) revisi desain, (6) uji coba produk, (7) revisi produk, (8) uji coba pemakaian, (9) revisi produk, dan (10) produk masal. Tahapan yang tersebut harus dijalankan oleh peneliti dalam rangka mengembangkan modul filsafat bahasa. Untuk itu memerlukan profesionalisme dalam rangka menghasilkan sebuah produk modul yang lebih bagus.

Potensi masalah dihasilkan dari kegiatan observasi pembelajaran filsafat bahasa dengan menggunakan modul yang telah ada. Selain kegiatan tersebut mengkaji teori-teori yang relevan dengan materi filsafat bahasa dari buku, jurnal. Peneliti juga mencatat teori atau konsep yang diambilkan dari beberapa sumber baik berupa buku, jurnal yang berkaitan dengan materi filsafat bahasa. Mengkaji metode scientific, dan nilai kearifan lokal untuk dapat diadopsi dalam setiap materi dalam modul yang akan dikembangkan. Pengumpulan data dengan angket respon mahasiswa terhadap desain modul dan teknik catat pada saat observasi kegiatan pembelajaran filsafat bahasa di kelas.
Kegiatan tersebut akan menghasilkan data kualitatif sebagai dasar untuk menyusun desain pengembangan modul filsafat bahasa.

Berdasarkan identifikasi kebutuhan, tujuan, materi, dan metode pengajaran dari modul yang akan dikembangkan akan mendapatkan data yang sangat dibutuhkan untuk keperluan pengembangan modul. Tujuan modul harus berdasarkan kajian dari tingkat kebutuhan mahasiswa terhadap materi mata kuliah. Tujuan tersebut diwujudkan dalam kompetensi pada setiap modul dengan disesuaikan dengan isi materi modul. Pemetaan kompetensi yang terdiri dari kognitif, afektif, dan psikomotorik yang dibutuhkan dalam pengembangan modul. Kompetensi tersebut harus disesuaikan dengan KKNI 2013 sebagai kerangka dalam menyusun materi yang dipergunakan untuk membentuk kemampuan kritis mahasiswa dengan menggunakan pendekatan scientific berbasis nilai kearifan lokal. Pemilihan judul modul dan isi materi yang relevan membutuhkan ketelitian dan kecermatan sehingga susunannya terlihat utuh, kronologis sehingga tidak akan menimbulkan persamaan materi untuk setiap modul.

Modul ini dirancang dengan memasukkan scientific dalam kegiatan belajar mahasiswa yang disajikan dalam bahasa yang sederhana dan praktis. Scientific harus menjadi ciri khas dalam analisis setiap materi dalam modul dalam dalam pertanyaan baik yang ada dalam materi ataupun dalam evaluasi. Nilai kearifan lokal seperti halnya scientific harus dimasukan dalam materi setiap modul sebagai dasar berpikir mahasiswa. Pengembangan modul harus melalui beberapa langkah dengan memasukan scientific dan nilai kearifan lokal dalam setiap materi dalam masing-masing modul.

Desain modul filsafat bahasa yang peneliti hasilkan dicoba untuk diajarkan kepada mahasiswa untuk melihat kekurangan dan kelebihan desain modul 
sebagai dasar untuk refisi draf modul filsafat bahasa. Kegiatan tersebut harus dilakukan secara berulang-ulang untuk menghasilkan draf modul yang diinginkan. Setelah draf filsafat bahasa hasil dari refisian, masih memerlukan uji lebih lanjut untuk mengetahui kelayakan dari draf modul. Sebelum dilakukan uji coba peneliti harus melakukan validasi draf modul kepada mahasiswa. Proses selanjutnya draf masih perlu proses refisi berdasarkan masukan dari mahasiswa melalui uji dengan angket respon mahasiswa.

Setelah hasil refisian draf modul filsafat bahasa tersebut dilakukan validasi ahli eksternal. Peneliti memilih dua validator ahli dari UNS Surakarta yaitu Dr. Muhamad Rohmadi, M. Hum dan dari STKIP PGRI Ponorogo Dr. Sutejo,M. Hum. Untuk validasi ahli pertanyaan sangat berhubungan dengan: kompetensi, materi modul, evaluasi, dan penutup. Untuk angket respon mahasiswa terhadap modul dan validasi ahli peneliti menggunakan analisis persentase digambarkan sebagai berikut: 0-25\% (kurang efektif), 26-50\% (cukup efektif), 51-75\% (efektif), dan 76-100\% (sangat efektif) (Sudarwati, 2013: 111).

Draf modul direfisi kembali berdasarkan masukan dari validator ahli dengan membagi draf modul filsafat bahasa menjadi dua jilid: jilid pertama "filsafat bahasa scientific berbasis nilai kearifan lokal" dan "filsafat bahasa kekinian". Tahap selanjutnya draf modul dilakukan uji coba dengan dua tahap pengujian yaitu; (1) pengujiam terbatas, dan (2) pengujian lebih luas dengan menggunakan model eksperimen "Single one shot case Study". Pre test dan post test dalam setiap modul dari modul pertama sampai terakhir terdapat evaluasi yang mencakup empat kompetensi berbahasa. Untuk menyimak dan berbicara dapat dinilai dengan kegiatan belajar diskusi kelas yang petunjuknya terdapat dalam modul. Kemampuan menulis penilaiannya berdasarkan pekerjaan mahasiswa yang dikumpulkan setelah kegiatan pembelajaran selesai. Rumus t sebagai berikut.

$$
\mathrm{t}=\frac{\left(\overline{X_{1}}-\overline{X_{2}}\right)}{s_{p} \sqrt{\frac{1}{n_{1}}+\frac{1}{n_{2}}}}
$$

$X=$ Nilai rata-rata

$\mathrm{Sp}=$ Standar deviasi gabungan

$\mathrm{n}=$ Jumlah sampel penelitian

$\mathrm{db}=(\mathrm{n} 1+\mathrm{n} 2-2)$

Data yang didapatkan dari pre test awal dengan post tes selanjutnya akan dibandingkan dengan mencari rata-ratanya, standar deviasinya untuk mendapatkan $\mathrm{t}$ hitung. Selanjutnya $t_{\text {hitung }}$ akan dibandingkan dengan $t$ tabel $(d b, 0,05)$ untuk mendapatkan simpulan. Jika $\mathrm{t}_{\text {hitung }}>\mathrm{t}_{\text {tabel }(\mathrm{db}, 0,05)}$ maka model layak untuk dilanjutkan atau efektif, jika $\mathrm{t}_{\text {hitung }}<\mathrm{t}_{\text {tabel }(\mathrm{db}, 0,05)}$ model tidak efektif atau tidak untuk digunakan dalam proses selanjutnya.

\section{HASIL DAN PEMBAHASAN \\ Potensi dan Masalah}

Tahap pertama yang dilakukan dalam pengembangan modul filsafat bahasa dengan melakukan kegiatan identifikasi masalah berkaitan dengan kebutuhan mahasiswa dalam proses pembelajaran. Kegiatan identifikasi masalah menemukan beberapa permasalahan sebagai berikut. Pertama, mahasiswa sekarang lebih suka mengerjakan pekerjaan saat perkuliahan. Banyak yang mengerjakan mata kuliah lainnya pada saat pembelajaran berlangsung. Mahasiswa lebih tertarik untuk mengerjakan pertanyaan dengan sedikit paksaan dengan memberikan reward berupa nilai jika mengerjakan tepat waktu dan mempunyai nilai kebenaran. Kedua, konsentrasi mahasiswa terpecah jika dari rumah sudah membawa persoalan dan dibawa sampai ruang kuliah. Ketiga, jumlah mahasiswa dalam suatu ruangan 
melebihi kapasitas membuat suasana kelas tidak kondusif, akan menggangu jalannya pembelajaran di kelas. Keempat, mahasiswa tidak mempunyai buku referensi yang berkaitan dengan mata kuliah bahasa sehingga hanya mengandalkan catatan yang diberikan dosen di kelas. Kelima, mahasiswa lebih suka memainkan smartphone di dalam kelas, walaupun sudah diperingatkan tidak boleh mengaktifkan smartphone dan sejenisnya pada saat perkuliahan.

Kecenderungan mahasiswa untuk mengerjakan pekerjaan yang diberikan oleh dosen pengampu mata kuliah lainnya pertemuannya setelah mata kuliah filsafat bahasa selesai. Potensi tersebut harus kita manfaatkan untuk membuat soal evaluasi yang berhubungan dengan materi mata kuliah. Evaluasi sangat diperlukan sekali dalam masa sekarang, disebabkan mahasiswa lebih suka untuk mengerjakan tugas di kelas dari pada di rumah. Mahasiswa lebih suka kegiatan yang secara nyata berhubungan dengan nilai mata kuliah. Berdasarkan pernyataan di atas, kegiatan yang tidak ada hubungannya dengan nilai akan dilaksanakan dengan baik walaupun ada yang hanya mengumpulkan hasil pekerjaannya tanpa melalui proses yang baik. Kegiatan praktis dan sederhana dengan membuat pertanyaan yang dapat mencakup berbagai kompetensi dalam setiap kegiatan belajar di kelas yang disesuaikan dengan materi dalam tiap modul. Untuk menjawab pertanyaan tersebut dosen harus mempersiapkan materi dalam bentuk tertulis dan mahasiswa harus membaca dan menyimak isi materi tersebut untuk mendapatkan jawaban yang benar. Aktivitas untuk menjawab pertanyaan mahasiswa dapat memanfaatkan smartphone untuk mencari referensi yang berhubungan dengan pertanyaan. Keberadaan alat elektronik tidak menjadi kendala dalam pembelajaran namun dapat memberikan kemudahan bagi mahasiswa untuk mencari jawaban. Bukan berarti mahasiswa kita ajarkan kegiatan untuk copy paste namun lebih ditekankan pada pemanfaatan teknologi untuk kegiatan produktif khususnya dalam proses belajar mengajar.

Identifikasi masalah dalam kegiatan belajar di kelas sebagai dasar untuk menentukan kompetensi dalam pengembangan modul filsafat bahasa. Kompetensi tersebut harus dapat diwujudkan dengan menyusun materi dan alat evaluasi yang tepat. Materi harus disusun dengan berdasarkan kompetensi baik; kognitif, efektif dan psikomotorik. Selain hal tersebut perencanaan instrumen untuk melihat kompetensi berbahasa mahasiswa terutama kemampuan berpikir kritis harus disesuaikan dengan materi modul.

\section{Pengumpulan Data}

Tahap selanjutnya dalam pengembangan modul filsafat bahasa mengumpulkan data dari proses identifikasi masalah pada tahap sebelumnya. Pengumpulan data menggunakan teknik simak dan teknik catat hal yang berhubungan dengan; materi tiap modul, metode scientific, nilai kearifan lokal, bentuk soal, sumber referensi yang terbaru, serta hasil identifikasi terhadap modul filsafat bahasa yang telah ada. Kegiatan tersebut mendapatkan data yang bersifat kualitatif sebagai dasar bagi desain modul filsafat bahasa. Modul filsafat bahasa yang telah ada sebelumnya dengan judul "filsafat bahasa dalam scientific berbasis nilai karakter jilid 1 dan 2" banyak sekali kekurangan yang perlu dievaluasi dan direfisi kembali. Bentuk tampilan dari buku yang kurang menarik dengan tulisan yang kurang jelas walaupun bukunya standar nasional. Cover belum mencerminkan dari materi filsafat bahasa sebenarnya karena gambarnya memperlihatkan anak Sekolah dasar yang sedang belajar hal ini tidak ada hubungannya dengan materi filsafat bahasa yang diajarkan di perguruan tinggi. Selain itu pendahuluan belum jelas kompetensi 


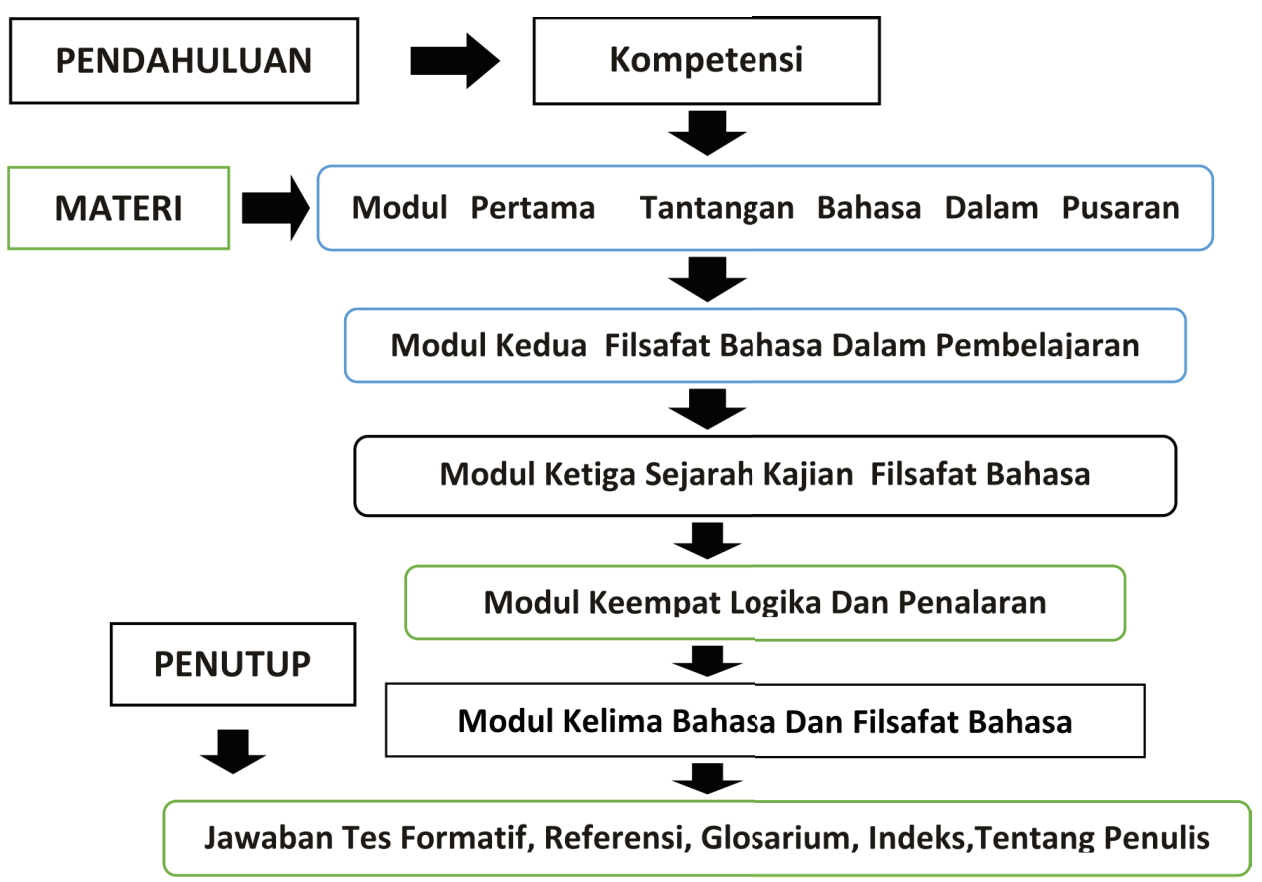

Gambar 1. Filsafat Bahasa Scientific Berbasis Nilai Karakter

dan kegiatan belajar. Urutan materi dalam setiap modul belum sesuai dengan urutan yang benar. Evaluasi belum dapat digunakan untuk mengukur kemampuan mahasiswa disebabkan materinya tidak ada dalam modul.

Berdasarkan gambar $1 \mathrm{di}$ atas hasil dari identifikasi masalah modul "filsafat bahasa scientific berbasis nilai karakter jilid 1. Urutannya modulnya tidak kronologis. Sedangkan pada bagian pendahuluan hanya terdiri dari kompetensi dan tidak ada kegiatan belajar yang dapat digunakan dalam mempelajari modul tersebut. Untuk lebih jelasnya uraian modul filsafat bahasa scientific berbasis nilai karakter dapat dilihat pada gambar 1. Berdasarkan gambar 1, urutan modul kurang sistematis hal ini dapat kita lihat dalam daftar isi. Modul pertama "tantangan bahasa dalam pusaran globalisasi", modul kedua "filsafat bahasa dalam pembelajaran", modul ketiga "sejarah kajian filsafat bahasa, modul keempat "logika dan penalaran', modul kelima "bahasa dan filsafat bahasa". Jika kita analisis mahasiswa pada awal modul sudah kita suruh untuk mengetahui dan menganalisis tantangan bahasa pada saat ini, padahal kontek dari mata kuliah filsafat bahasa berkaitan dengan daya pikir kritis mahasiswa. Mengenalkan hakikat filsafat bahasa kepada mahasiswa seharusnya yang lebih dahulu diajarkan. Setelah melalui kegiatan identifikasi masalah tahap selanjutnya melakukan perencanaan modul.

\section{Perencanaan (Desain) Modul}

Tahap selanjutnya dalam penelitian pengembangan ini adalah melakukan kegiatan perencaaan pengembangan modul berdasarkan hasil dari identifikasi masalah. Urutan kronologis modul, isi materi, evaluasi, kegiatan belajar yang harus memasukan unsur scientific dan nilai kearifan lokal. Kompetensi yang menjadi tujuan dalam setiap kegiatan pembelajaran harus disesuaikan dengan materi yang dimasukan dalam setiap modul. Untuk itu perlu perencaaan desain modul yang akan dikembangkan dengan memperhatikan kekurangan pada moul sebelumnya. Selain hal tersebut pengembangan modul disesuaikan dengan kondisi kekinian 
yang sangat berhubungan dengan hilangnya nilai, moral, karakter mahasiswa disebabkan pengaruh budaya.

Santyasa (2009) untuk merancang materi modul terdapat lima kategori kapabilitas yang dapat dipelajari dari proses belajar mengajar yang berupa informasi verbal, keterampilan intelektual, strategi kognitif, sikap, dan keterampilan motorik. Modul pengembangan diharapkan dapat meningkatkan kompetensi mahasiswa khususnya berhubungan dengan kompetensi; menyimak, membaca, manulis dan berbicara sebagai modul penting bagi mahasiswa.

Prastowo (2014:106) modul adalah sebuah bahan ajar yang disusun secara sistematis dengan bahasa yang mudah dipahami oleh peserta didik sesuai tingkat pengetahuan dan usia mereka, agar mereka dapat belajar sendiri (mandiri) dengan bantuan atau bimbingan yang minimal dari pendidik". Modul filsafat bahasa hasil pengembangan ini menggunakan metode pembelajaran scientific dengan mengedepankan langkah berpikir yang mendahulukan fakta sebagai dasar kajian untuk mengambil sebuah simpulan atau keputusan. Selain itu nilai kearifan lokal sebagai dasar dalam berpikir sehingga hasil simpulannya mempunyai nilai kebermaknaan.

Kegiatan pembelajaran yang tercantum dalam setiap modul dengan kegiatan diskusi kelompok sangat cocok bagi pembelajaran mahasiswa dewasa ini. Mahasiswa dapat memanfaatkan segala media internet dengan menggunakan smartphone untuk mencari referensi pada saat diskusi kelas berlangsung. Kegiatan diskusi kelas akan berjalan dengan lancar dengan pertanyaan dan jawaban secara bergantian. Kegiatan belajar akan memberikan kebiasaan bagi mahasiswa sehingga akan membentuk daya berpikirnya lebih kritis.

Fauziah, Abdullah, dan Lukman Hakim (2013: 165-178) langkah-langkah pembelajaran scientific science (pendekatan
Ilmiah): (1) mengamati, membaca, mendengar, menyimak, melihat (tanpa atau dengan alat); (2) menanya mengajukan pertanyaan tentang informasi yang tidak dipahami dari apa yang diamati atau pertanyaan untuk mendapatkan informasi tambahan tentang apa yang diamati; 3) menalar melakukan eksperimen, membaca sumber lain selain buku teks, mengamati objek/ kejadian/ aktivitas, wawancara dengan nara sumber; (4) mengolah informasi/mencoba mengolah informasi yang sudah dikumpulkan baik terbatas dari hasil kegiatan mengumpulkan/eksperimen mau pun hasil dari kegiatan mengamati dan kegiatan mengumpulkan informasi; dan (5) mengkomunikasikan menyampaikan hasil pengamatan, kesimpulan berdasarkan hasil analisis secara lisan, tertulis, atau media. Scientific dalam proses indentifikasi pada penelitian pengembangan ini peneliti tidak membuat bab tersendiri namun scientific mutlak dijadikan landasan berpikir mahasiswa dalam setiap menjawab pertanyaan baik dalam modul maupun di luar modul.

Varelas (2009: 45) metode ilmiah sebenarnya telah dilakukan oleh mahasiswa pada saat membuat pertanyaan ilmiah otentik, hipotesis mereka menjawab sementara berdasarkan teori yang ada dan dilakukan suatu tes mahasiswa telah menggunakan metode ilmiah walaupun urutannya berubah-ubah sesuai dengan kebutuhan di lapangan. Metode ilmiah tidak selalu berurutan namun dapat disesuaikan dengan kebutuhan di lapangan. Jawaban pertanyaan evaluasi dalam setiap modul yang dikembangkan dapat digunakan untuk melatih mahasiswa berpikir kritis yang didasarkan oleh metode scientific berbasis nilai kearifan lokal. Kearifan lokal dapat didefinisikan sebagai suatu kekayaan budaya lokal yang mengandung kebijakan hidup, pandangan hidup (way of life) yang mengakomodasi kebijakan (wisdom) dan kearifan hidup (Suyatno, S, 2016). 


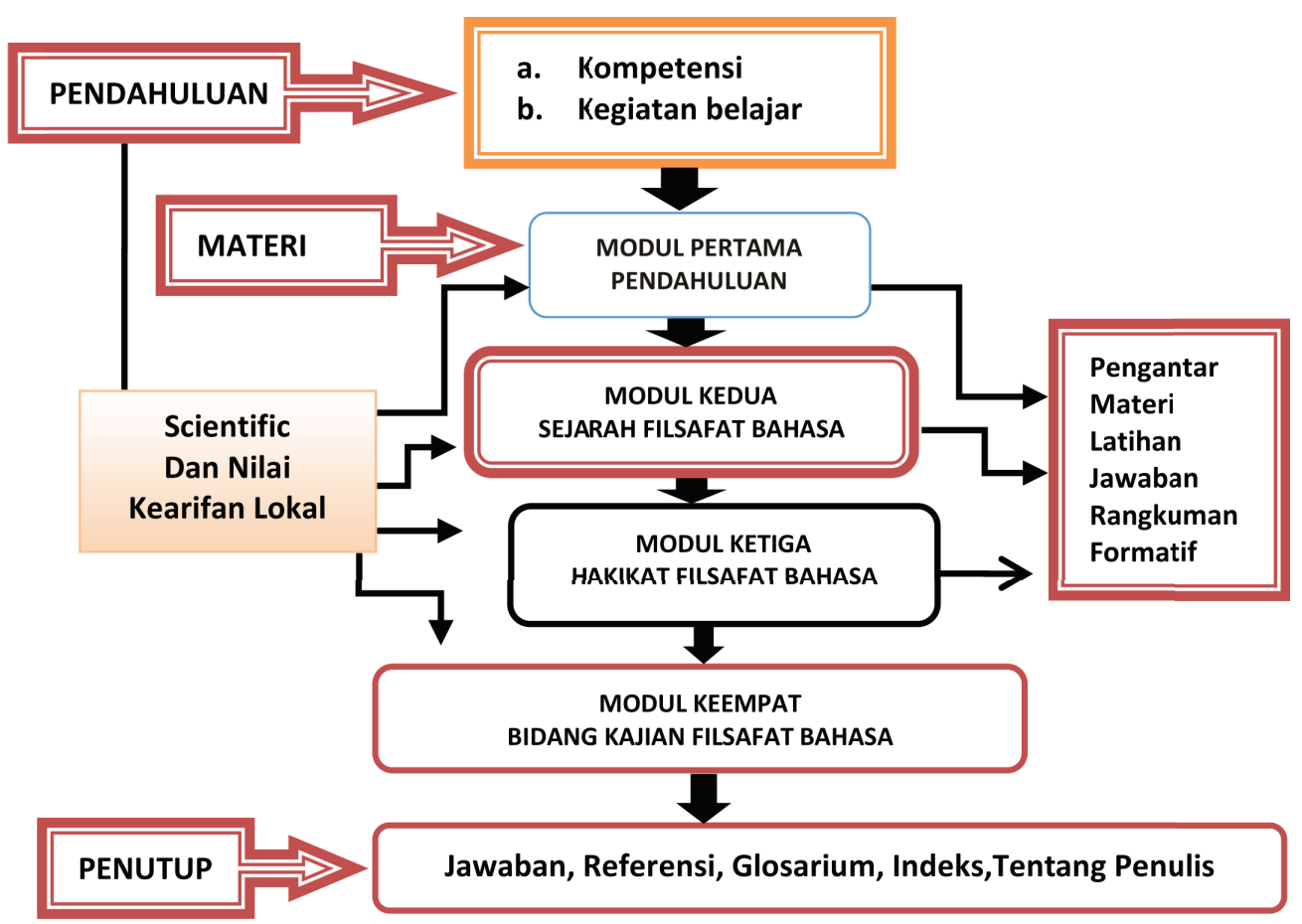

Gambar 2. Filsafat Bahasa Scientific Berbasis Nilai Kearifan Lokal

Berdasarkan uraian di atas jawaban evaluasi mahasiswa baik secara lisan maupun tulis sebagai dasar bagi penilaian kompetensi berbahasa mahasiswa. Hasil rata-rata kompetensi membaca, meyimak, berbicara, dan menulis sebagai dasar bagi analisis data yaitu uji t yang disesuaikan dengan kegiatan uji coba modul secara terbatas maupun luas. Uji $\mathrm{t}$ digunakan untuk menguji efektifitas modul dalam kegiatan pembelajaran filsafat bahasa scientific berbasis nilai kearifan lokal dan filsafat bahasa kekinian. Jika $t_{\text {hitung }}$ lebih besar dari $t_{\text {tabel }}$ modul filsafat bahasa yang telah dikembangkan dapat meningkatkan kompetensi bahasa mahasiswa.

Berdasarkan gambar 2 setelah pengembangan modul, terdiri dari: (1) pendahuluan meliputi kompetensi, dan kegiatan belajar; (2) materi dalam setiap modul yang meliputi pengantar, beberapa tema dalam modul, evaluasi, rangkuman, jawaban evaluasi, dan tes formatif; (3) penutup terdiri dari; daftar pustaka, glosarium, indeks, dan tentang penulis. Berdasarkan gambar 2 modul yang dikembangkan belum dikelompokkan berdasarkan klasifikasi seperti tersebut di atas. Perlu adanya pengembangan sehingga modul terdiri dari 3 bagian yaitu; pendahuluan, materi, dan penutup.

Modul mata kuliah filsafat bahasa kompetensi yang ingin dicapai merubah pola pikir kritis mahasiswa menjadi pola pikir scientific yng selalu berdasarkan paa nilai kearifan lokal. Unsur scientific dan nilai kearifan lokal harus dimasukan dalam pengembangan modul filsafat bahasa sebagai dasar dalam berpikir. Filsafat bahasa merupakan mata kuliah yang bertujuan untuk berpikir secara mendalam terhadap objek yang berupa bahasa. Proses berpikir mahasiswa harus didasarkan scientific dan nilai kearifan lokal agar hasil dari proses berpikirnya dalat menghasilkan pemikiran yang lebih baik dan bermanfaat.

Berdasarkan hasil respon mahasiswa dan validasi ahli pengembangan modul filsafat bahasa menghasilkan 2 jilid yaitu; filsafat bahasa scientific berbasis nilai kearifan lokal dan filsafat bahasa kekini- 


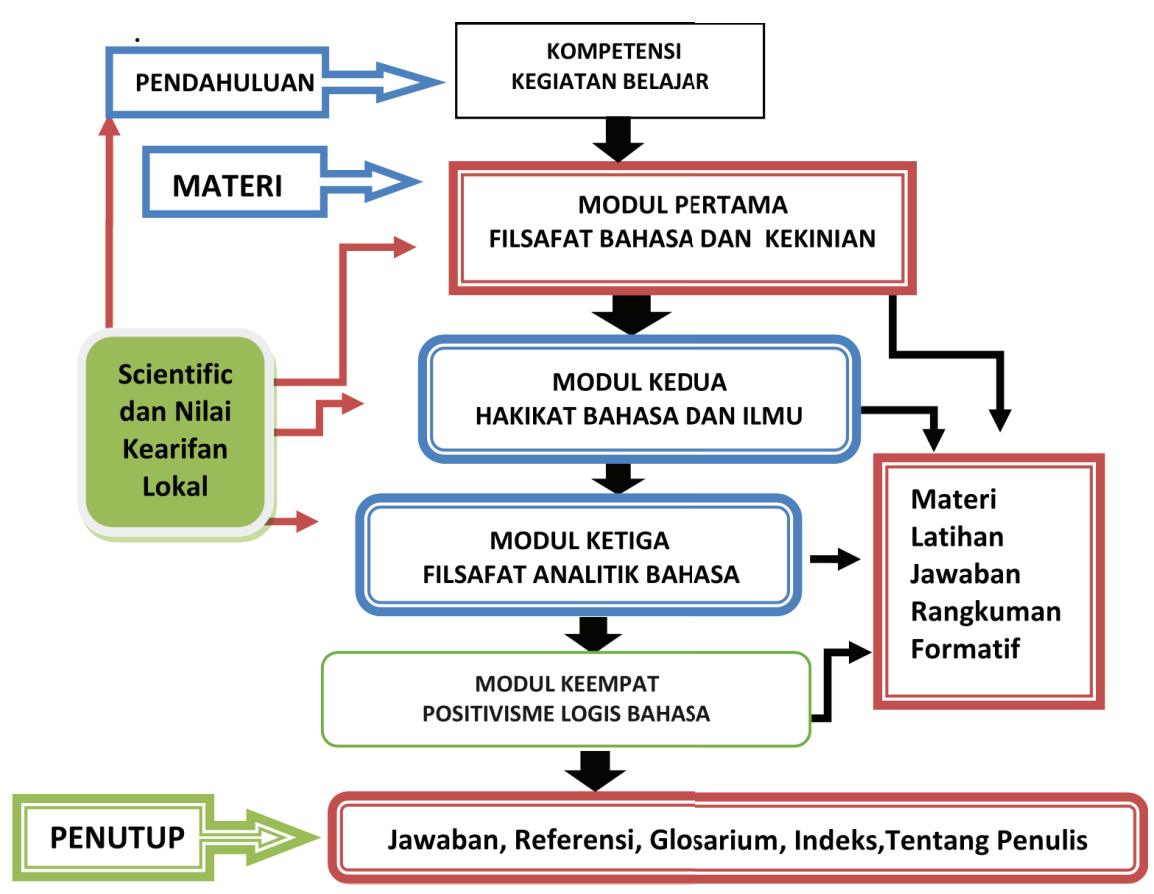

Gambar 3. Pengembangan Filsafat Bahasa Kekinian

an. Modul filsafat bahasa scientific berbasis nilai kearifan lokal kami susun menjadi beberapa modul sebagai berikut: (1) modul pendahuluan, terdiri dari: filsafat bahasa scientific M4S, scientific dalam modul, dan rangkuman; (2) materi pertama modul kedua "sejarah filsafat bahasa"; (3) modul ketiga "hakikat filsafat bahasa"; dan (4) bidang kajian filsafat bahasa. Untuk materi dalam modul 2, 3, dan 4 terdiri dari; standar kompetensi, kegiatan belajar, materi, rangkuman, evaluasi, dan formatif. Pada bagian penutup terdiri dari: kunci jawaban tes formatif, referensi, glosarium, indeks, dan tentang penulis.

Scientific dan nilai kearifan lokal dalam pendahuluan dijabarkan dalam bentuk kompetensi dan kegiatan belajar. Selain yang tersebut di atas scientific dan nilai kearifan lokal terdapat dalam materi yang terdapat dalam setiap sub bab modul sebagai dasar dalam berpikir kritis mahasiswa. Pada hakikatnya scientific merupakan bagian kajian filsafat bahasa yang merupakan kajian ontologi bahasa dan epistemologi bahasa. Nilai kearifan lokal merupakan kajian axiologi bahasa yang harus ada dalam setiap pengambilan keputusan yang berhubungan dengan bahasa. Ilmu pengetahuan yang dihasilkan dari proses berpikir dengan menggunakan langkah-langkah ilmiah harus mempunyai hasil yang bermanfaat dan berguna bagi masyarakat. Kemampuan berpikir kritis tersebut untuk membendung budaya globalisasi yang materialisme dan individualisme. Kearifan lokal harus dapat diimplementasikan dalam modul agar nasibnya tidak seperti benda pusaka seperti keris hanya sebagai pajangan belaka.

Modul filsafat bahasa peneliti kembangkan menjadi dua bagian yaitu bagian materi dan penutup. Untuk pendahuluannya sudah ada pada "filsafat bahasa scientific berbasis nilai kearifan lokal" sedangkan untuk "filsafat bahasa kekinian" merupakan lanjutan dari modul tersebut. Tujuan peneliti mencoba untuk membedakan judul modul agar mahasiswa tertarik untuk mempelajari filsafat bahasa. Cover untuk dua judul filsafat bahasa berbeda untuk filsafat bahasa scientific berbasis nilai kearifan lokal setingnya pantai Ke- 
layar yang dapat mewakili scientific (keindahan alam) dan kearifan lokal (masih alami) mengandung kearifan hidup.

Berdasarkan gambar 3 "filsafat bahasa kekinian" yang di dalamnya terdiri dari empat modul; (1) filsafat bahasa kekinian, (2) hakikat bahasa dan ilmu, (3) filsafat analitik bahasa, dan (4) positivisme logis bahasa sangat berkaitan dengan penggunaan bahasa kekinian. Untuk co-ver depannya gambar gadis yang sedang berselfie yang merupakan perwujudan dari materi bahwa kekinian identik dengan foto selfie khususnya generasi muda sebagai akibat dari perubahan budaya akibat dari kemajuan ilmu pengetahuan dan teknologi. Untuk materi dalam modul 1, 2, 3 , dan 4 terdiri dari; standar kompetensi, kegiatan belajar, materi, rangkuman, evaluasi, dan formatif.

Standar kompetensi yang merupakan tujuan pembelajaran setiap modul baik modul pertama sampai modul keempat. Berdasarkan gambar 3 standar kompetensi sebagai dasar bagi pengembangan materi yang disusun dengan selalu memasukan unsur scientific dan nilai kearifan lokal. Adapun kompetensi yang ingin dicapai dalam modul hasil pengembangan harus mengacu pada KKNI 2013 sebagai berikut: (1) mahasiswa diharapkan menguasai konsep metode ilmiah dalam setiap menyelesai-an masalah; (2) mahasiswa diharapkan mempunyai kepekaan terhadap permasalahan nyata di masyarakat; (3) mahasiswa mempunyai kepemimpinan; (4) mahasiswa mampu untuk mengendalikan setiap ada persoalan dan mencari solusi pemecahan. Kompetensi tersebut harus tercakup dalam setiap modul diharapkan dapat membentuk pola pikir ilmiah untuk dapat meningkatkan kompetensi bahasa mahasiswa. Kompetensi tersebut sangat berkaitan dengan kemampuan berbahasa mahasiswa yang terdiri dari kompetensi; membaca, menyimak, menulis, dan berbicara.
Selanjutnya pada bagian penutup terdiri dari: kunci jawaban tes formatif, referensi, glosarium, dan tentang penulis. Scientific dan nilai kearifan lokal selalu ada dalam setiap modul baik modul pertama sampai modul keempat. Daryanto (2013) karakteristik modul yang baik adalah: (1) self instruction, memuat tujuan pembelajaran yang jelas, menggambarkan pencapaian kompetensi, memuat materi yang dikemas dalam unit-unit kegiatan yang kecil/spesifik, contoh dan ilustrasi yang mendukung kejelasan pemaparan materi pembelajaran, soal-soal latihan dan tugas untuk mengukur penguasaan siswa terhadap materi, materi yang disajikan sesuai dengan lingkungan siswa, menggunakan bahasa yang sederhana dan komunikatif, rangkuman pembelajaran, instrumen penilaian yang memungkinkan siswa untuk melakukan penilaian mandiri; dan terdapat informasi tentang rujukan, atau referensi yang mendukung pembelajaran; (2) self contained, apabila seluruh materi pembelajaran termuat dalam modul bertujuan untuk memberikan kesempatan siswa untuk mempelajari standar kompetensi secara tuntas, karena materi belajar dikemas ke dalam satu kesatuan yang utuh; 3) berdiri sendiri, modul dapat berdiri sendiri atau tidak tergantung pada bahan ajar atau media lain.

Berdasarkan gambar 2 dan 3 di atas modul yang peneliti kembangkan telah memenuhi ketiga ciri yang tersebut di atas yaitu: (1) dalam setiap modul terdapat standar kompetensi yang harus sebagai tujuan dalam penyelesaian materi dalam setiap modul; (2) seluruh materi yang digunakan untuk pencapaian standar kompetensi telah diuraikan dalam setiap modul; dan (3) modul pertama sampai keempat dapat berdiri sendiri disebabkan rangkuman, evaluasi, dan formatif tidak berkaitan langsung dengan materi dalam modul lainnya. Dengan demikian modul filsafat bahasa telah memenuhi syarat sebagai sebuah modul. Dengan demikian 
proses kegiatan pengembangan dapat dilanjutkan ke langkah validasi ahli dan respon mahasiswa terhadap desain modul filsafat bahasa.

\section{Validitas Modul}

Pengembangan modul "Filsafat Bahasa dalam Scientific Berbasis Nilai Kearifan Lokal" dan Filsafat bahasa kekinian berdasarkan hasil dari: validasi ahli, angket penilaian mahasiswa serta uji coba modul di kelas. Pada dasarnya penelitian diharapkan dapat menghasilkan modul yang berstandar Nasional setelah melalui uji kompetensi dari ahli filsafat bahasa, ahli pembelajaran, serta ahli modul yang dapat dijadikan sumber belajar pada matakuliah filsafat bahasa atau Linguistik baik jurusan pendidikan Bahasa indonesia maupun jurusan yang relefan lainnya. Modul Filsafat dalam scientific berbasis pendidikan karakter dapat dipergunakan untuk meningkatkan kompetensi berbahasa mahasiswa mahasiswa Program Studi Pendidikan Bahasa dan Sastra Indonesia STKIP PGRI Pacitan dlam rangka meningkatkan kompetensi lulusan.

Pengembangan desain modul dengan mengikuti langkah sebagai berikut: (1) mengembangkan modul yang ada dengan membuatnya lebih cocok dengan kebutuhan dan harapan mahasiswa, instruktur, dan lembaga sekolah; (2) pengembangan modul ini dilakukan melalui komunikasi dan diskusi dengan mitra berkolaborasi dengan mahasiswa, dosen, dan lembaga; (3) ada fase validasi melalui komunikasi dengan mitra berkolaborasi dan pengguna, mahasiswa, dosen, dan lembaga; dan (4) pengembangan modul secara kualitatif diukur, melalui survei untuk mengumpulkan data dalam bentuk komentar dan saran untuk meningkatkan modul itu sendiri, dan kuantitatif diukur melalui persentase untuk mengetahui efektivitas modul (Sudarwati, 2013: 115).

Proses identifikasi masalah berkaitan dengan mahasiswa, dosen pengampu mata kuliah dan ketersediaan sarana dan prasarana di lembaga. Mahasiswa lebih tertarik pada kegiatan yang praktis yang berhubungan dengan nilai mata kuliah. Strategi pembelajaran dosen harus didukung oleh sarana dan prasarana pembelajaran di kelas dalam hal ini ketersediaan LCD atau HDMI. Keterbatasan sarana dan prasarana harus mengembangankan modul mata kuliah yang tidak lagi tergantung pada sarana di ruang kuliah. Pertimbangan tersebut menjadi dasar untuk pengembangan modul filsafat bahasa. Kegiatan belajarnya sangat praktis dan sederhana tidak memerlukan media belajar lainnya dan dapat dilakukan dimanapun saja dalam waktu yang berbeda.

Hasil dari pengembangan modul yang berupa desain filsafat bahasa memerlukan proses validasi dengan membentuk kegiatan diskusi dengan mahasiswa sebagai pengguna modul. Menggunakan teknik angket respon mahasiswa terhadap modul filsafat bahasa scientific. Isi angket sebagai berikut: (1) penyajian modul menarik karena dilengkapi dengan gambar, tabel, rangkuman, glosarium, dan daftar pustaka; (2) cakupan materi jelas dan kronologis; (3) masalah sesuai dengan kehidupan sehari-hari; (4) mahasiswa lebih mudah memahami materi filsafat bahasa; (5) bahasa yang digunakan komunikatif dan mudah dipahami; (6) modul sesuai dengan EYD; dan (7) struktur kalimat jelas dan sederhana.

Berdasarkan dari hasil respon angket mahasiswa terhadap modul filsafat bahasa scientific berbasis nilai kearifan lokal dan filsafat bahasa kekinian didapatkan respon mahasiswa 80,2 \%. Berdasarkan hasil angket respon mahasiswa peneliti berusaha untuk merefisi kembali modul filsafat bahasa tersebut. Selain itu modul kurang menarik karena tulisannya tidak begitu jelas sehingga akan menggurangi daya tarik mahasiswa untuk membacanya. Ejaannya terutama dalam kutipan 
masih banyak yang keliru dan penggunaan tanda miring pada huruf asing masih terlihat kesalahan penulis

Modul akan dilakukan proses refisi berdasarkan hasil ari angket respon mahasiswa. Proses selanjutnya dilakukan uji validasi ahli terhadap efektifitas dari desain modul filsafat bahasa tersebut. Peneliti menggunakan dua validator yang terdiri dari: ahli pembelajaran bahasa dan sastra dari UNS Surakarta Dr. Muhammad Rohmadi, S.S, M.Hum, dan Dr.H. Sutejo, M.Hum. Adapun penilaian meliputi 3 aspek yaitu: (1) struktur modul; (2) organisasi penulisan modul; dan (3) bahasa. Struktur modul berhubungan dengan: cover, kata pengantar, daftar isi, kompetensi, kegiatan pembelajaran, organisasi penyajian umum, tampilan modul, keterkaitan yang konsisten dari modul. Organisasi penulisan materi aspek yang dinilai terdiri dari; cakupan materi, kejelasan dan urutan materi, ketepatan materi dengan SK, keterkaitan materi dengan konteks. Sedangkan bahasa aspek yang dinilai validator terdiri dari; penggunaan bahasa sesuai dengan EYD, bahasa yang digunakan komunikatif, dan kesederhanaan struktur kalimat.

Adapun aspek penilaiannya meliputi: (1) struktur modul (cover, kata pengantar, daftar isi, kompetensi, kegiatan pembelajaran, organisasi penyajian, tampilan modul, keterkaitan antar materi); (2) organisasi penulisan materi (cakupan materi, kejelasan materi, keterkaitan materi dengan kompetensi, keterkaitan materi dengan konteks); dan (3) penggunaan bahasa sesuai dengan EYD. Hasil dari validasi kesalahan tanda baca setelah titik dua (:) tidak boleh diikuti oleh huruf kapital. Penulisan kutipan pada awal kalimat tidak perlu menambahkan (menurut, pendapat, kata lainnya) sebagai contohnya; Suryanto (2015: 3) bahasa sebagai suatu sistem tanda, lambang yang tersistem. Modul terlalu banyak halamannya sehingga perlu dijadikan dua jilid.
Kesalahan yang harus direfisi lainnya aspek penulisan huruf asing harus ditulis miring dan paragraf awal bab harus ditulis rata kanan tidak masuk ke dalam 5 ketukan. Untuk paragraf yang lainnya tidak berubah sesuai dengan yang sudah ada. Adapun skor penilaian rata-rata dari validator tersebut $89 \%$ modul sudah layak digunakan.

Berdasarkan hasil validasi ahli tersebut desain modul direfisi kembali dengan memperhatikan masukan dan arahan dari tim validator. Peneliti juga melakukan proses refisi sehingga modul filsafat bahasa layak sebagai modul untuk mata kuliah filsafat bahasa. Modul pembelajaran harus mempunyai ciri-ciri sebagai berikut: (1) self instructional, siswa mampu membelajarkan diri sendiri, tidak tergantung pada pihak lain; (2) self contained, seluruh materi pembelajaran yang dipelajari terdapat didalam satu modul utuh; (3) stand alone, modul yang dikembangkan tidak tergantung pada media lain; (4) adaptif, terhadap perkembangan ilmu dan teknologi; (5) user friendly, bersahabat dengan pemakainya; dan (6) konsistensi, dalam penggunaan font, spasi, dan tata letak (Anwar, 2010).

Berdasarkan hasil respon mahasiswa, validasi ahli dan teori di atas peneliti melakukan proses refisi dan edit kembali desain modul. Berdasarkan hasil refisi modul filsafat bahasa terdiri dari 3 bagian yaitu; (1) pendahuluan, (2) materi, (3) dan penutup. Pendahuluan peneliti kembangkan menjadi 2 yang terdiri dari kompetensi mahasiswa setelahmempelajari modul, dan strategi kegiatan belajar modul bersangkutan. Untuk materi peneliti kembangkan dengan memberikan pengantar, sub materi, latihan, rangkuman, dan evaluasi. Sedangkan untuk bagian penutup peneliti tidak merubah yang terdiri dari; daftar pustaka, glosarium, indeks, dan penulis.

Berdasarkan saran dan arahan dari validator, desain modul filsafat bahasa di- 
jadikan 2 jilid mendapatkan respon yang baik disebabkan halamannya cukup tebal sesuai dengan yang telag direncanakan. Urutan modulnya tidak mengalami perubahan dimana untuk modul filsafat bahasa scientific berbasis nilai kearifan lokal terdiri dari empat modul dan satu modul pendahuluan. Sedangkan filsafat bahasa kekinian terdiri dari empat modul seperti dalam gambar 3. Proses refisi masih terus dilakukan terutama berkaitan dengan penutup yang terdiri dari; indeks, glosarium, daftar pustaka. Glosarium, indeks, dan daftar pustaka peneliti sesuaikan dengan masing-masing modul. Dengan demikian antara modul "filsafat bahasa scientific berbasis nilai kearifan lokal" dan 'filsafat bahasa kekinian" merupakan hasil produk dari pengembangan modul filsafat bahasa. Selain itu juga masih banyak kesalahan tanda baca terutama huruf asing yang tidak dimiringkan penulisannya.

Hasil refisian kedua modul perlu diuji efektifitasnya atau kelayakannya. Adapun uji tersebut tediri dari dua uji: (1) uji terbatas dengan metode eksperimen single one shot case study; dan (2) uji luas dengan eksperimen one group pretest-postest. Kedua uji tersebut pada dasarnya membandingkan nilai rata-rata kompetensi mahasiswa pada setiap uji coba dengan mencari standar deviasinya untuk mendapatkan $\mathrm{t}$ hitung. Untuk proses selanjutnya hasil refisi modul tersebut masih dilakukan uji selanjutnya untuk mengetahui kelayakan dari modul tersebut apakah dapat diproduksi secara masal atau masih perlu adanya perbaikan lagi.

\section{Hasil Uji Modul Terbatas dan Luas}

Sugiyono (2010: 407) metode R\&D adalah metode penelitian yang digunakan untuk menghasilkan produk tertentu dan menguji keefektifan produk tersebut. Produk dalam penelitian ini adalam modul filsafat bahasa dalam scientific berbasis nilai kearifan lokal dan filsafat bahasa kekinian. Pengujian untuk menguji efektifitas kedua modul tersebut dilakukan dua tahap yaitu; (1) pengujian terbatas dan (2) pengujian luas.

\section{Pengujian Terbatas}

Pengujian terbatas dilakukan di STKIP PGRI Pacitan dengan empat kali pengujian yaitu; uji coba 1 , uji coba 2 , uji coba 3 , dan uji coba 4 . Tahap uji terbatas dengan menggunakan metode eksperimen (single one shot case study). Hasil uji coba yang keempat mahasiswa mengerjakan soal evaluasi pada modul secara mandiri. Mahasiswa mengerjakan dengan sangat baik dan memanfaatkan semua media yang dimilikinya. Adapun materi yang harus dikerjakan yaitu pada evaluasi pada setiap akhir modul baik modul filsafat bahasa scientific berbasis nilai kearifan lokal dan filsafat bahasa kekinian.

Evaluasi dalam setiap modul merupakan perpaduan antara kompetensi membaca, menyimak, dan menulis. Mahasiswa akan menjawab pertanyaan dalam evaluasi harus terlebih dahulu membaca dan menyimak materi yang ada dalam setiap modul sebelum ditulis dalam lembar jawaban. Kemampuan menulis sangat beragam antara mahasiswa satu dengan lainnya hal ini tercermin dari jawaban yang berupa tulisan pada lembar jawaban. Jawaban mahasiswa terdapat tiga katagori; (1) menjawabnya secara berkelompok 3 orang sehingga jawabannya hampir sama, (2) menjawabnya secara mandiri karena tempat duduknya berbeda tidak menutup kemungkinan jawabannya akan dipinjam oleh temannya sehingga sama dengan temannya, (3) mahasiswa yang sudah mandiri sesuai dengan kemampuannya. Untuk katagori yang mandiri dosen dapat menjamin bahwa tipe mahasiswa yang demikian mempunyai komptensi yang lebih tinggi jika dibandingkan dengan lainnya. Hasil rata-rata kompetensi mahasiswa untuk 4 kali uji coba penyebaran nilainya ada yang tinggi, sedang, dan rendah. Adapun hasil ujicoba terbatas dapat dilihat di Tabel 1. 
Tabel 1. Data hasil uji coba terbatas dengan tingkat kesalahan 5\%

\begin{tabular}{cccccccc}
\hline Kegiatan & Jumlah $\mathbf{n}$ & $\begin{array}{c}\mathbf{X} \\
\text { Rata-rata }\end{array}$ & Standar Deviasi & Standar Deviasi & $\begin{array}{c}\mathbf{t} \\
\text { Hitung }\end{array}$ & $\begin{array}{c}\mathbf{d f} \\
(\mathbf{d b})\end{array}$ & $\begin{array}{c}\mathbf{t} \\
\text { Tabel }\end{array}$ \\
\hline Uji coba 1 & 20 & 11,16 & 1,56 & & & & \\
uji coba 2 & 20 & 13,05 & 2,43 & 2,04 & 2,94 & 38 & 2,021 \\
Uji coba 1 & 20 & 11,16 & 1,56 & & & & \\
uji coba 3 & 20 & 14,85 & 1,41 & 1,48 & 7,89 & 38 & 2,021 \\
Uji coba 1 & 20 & 11,16 & 1,56 & & & & \\
Uji coba 4 & 20 & 16,45 & 2,14 & 1,87 & 8,96 & 38 & 2,021 \\
Uji coba 2 & 20 & 13,05 & 2,43 & & & & \\
Uji coba 3 & 20 & 14,85 & 1,41 & 2,98 & 2,88 & 38 & 2,021 \\
Uji coba 2 & 20 & 13,05 & 2,43 & & & & \\
Uji coba 4 & 20 & 16,45 & 2,14 & 2,29 & 4,69 & 38 & 2,021 \\
Uji coba 3 & 20 & 14,85 & 1,41 & & & & \\
Uji coba 4 & 20 & 16,45 & 2,14 & 1,81 & 2,79 & 38 & 2,021 \\
\hline
\end{tabular}

Berdasarkan tabel $1 \mathrm{di}$ atas pengujian terbatas dilakukan empat kali yaitu, ujicoba 1, 2, 3, dan 4. Modul dapat dinyatakan efektif jika hasil perhitungan $t_{\text {hitung }}$ lebih besar dari $t_{\text {tabel }}$ dengan derajat bebas 35 dengan kesalahan $5 \%$. Untuk menghitung t hitung terlebih dahulu harus dicari terlebih dahulu standar deviasi untuk hasil pre test ataupun hasil post test masingmasing uji coba. Setelah didapatkan hasil rata-rata nilai post test dan pre test dan masing-masing standar deviasinya baru dihitung deviasi gabungan untuk menghitung $t_{\text {hitung }}$.

Untuk mengetahui efektifitas modul hasil pengembangan pada uji coba pertama peneliti membandingkan hasil pre test dan hasil akhir dari post test setelah kegiatan pembelajaran selesai. Berdasarkan tabel 1 nilai rata-rata ujicoba $2(13,05)$ lebih besar dari uji coba $1(11,16)$. Hasil pengujian signifikansi diperoleh $\mathrm{t}_{12}$ hitung 2,94 lebih besar dari $t_{\text {tabel }(38,0,05)} 2,021$. Dengan demikian perbedaan hasil uji coba 1 dan 2 signifikan. Modul filsafat bahasa efektif digunakan dalam kegiatan uji coba pertama disebabkan dapat meningkatkan kompetensi mahasiswa. Peningkatan nilai pada post test memperlihatkan bahwa modul filsafat bahasa scientific berbasis nilai kearifan lokal dan filsafat bahasa kekinian efektif digunakan dalam kegiatan uji coba pertama.

Setelah membandingkan ujicoba 1 peneliti juga membandingkan antara ujicoba 1 dan 3, untuk nilai rata-rata uji coba 3 $(14,8)$ lebih besar dari uji coba $1(11,16)$. Pengujian signifikansi diperoleh $\mathrm{t}_{13 \text { hitung }}$ 7,89 lebih besar dari $t$ tabel $(38,0,05) 2,021$. Simpulannya terdapat perbedaan hasil ujicoba 1 dan 3 signifikan. Modul filsafat bahasa efektif digunakan dalam kegiatan belajar karena dapat meningkatkan kompetensi bahasa.

Perbandingkan antara uji coba 1 dan 4, didapatkan untuk nilai rata-rata uji coba $4(8,96)$ lebih besar dari uji coba $1(11,16)$. Pada taraf pengujian signifikansi diperoleh $\mathrm{t}_{14 \text { hitung }} 2,94$ lebih besar dari $\mathrm{t}$ tabel $(38,0,05)$ 2,021 . Simpulan dari hasil perhitungan uji $\mathrm{t}$ terdapat perbedaan hasil ujicoba 1 dan 4. Simpulannya modul filsafat bahasa efektif atau layak digunakan karena dapat meningkatkan kompetensi mahasiswa terutama terdapat perbedaan yang signifikan antara uji coba pertama dan keempat. Deangan demikian dalam perbandingan uji coba 1 dan 4 modul filsafat bahasa scientific dan filsafat bahasa kekinian dapat meningkatkan kompetensi mahasiswa terutama kompetensi berbahasa. 
Perbandingan selanjutnya yang terlihat dalam tabel 1 uji coba 2 dan 3 . Nilai rata-rata uji coba $3(14,85)$ lebih besar dari uji coba $2(13,05)$. Pengujian signifikansi diperoleh $\mathrm{t}_{23 \text { hitung }} 2,88$ lebih besar dari $\mathrm{t}_{\text {tabel }}$ $(38,0,05) 2,021$. Dengan demikian perbedaan hasil ujicoba 2 dan 3 signifikan. Modul filsafat bahasa scientific dan filsafat bahasa kekinian efektif digunakan karena dapat meningkatkan kompetensi mahasiswa.

Tahap perbandingan selanjutnya kita bandingkan antara uji coba 2 dan 4, untuk nilai rata-rata uji coba $4(16,45)$ lebih besar dari uji coba $1(13,05)$. Pengujian signifikansi diperoleh $\mathrm{t}_{24 \text { hitung }} 4,69$ lebih besar dari $t t_{\text {tabel } 938,0,05)} 2,021$. Dengan demikian perbedaan hasil ujicoba 2 dan 4 signifikan. Modul filsafat bahasa efektif digunakan karena dapat meningkatkan kompetensi mahasiswa.

Perbandingan terakhir dalam tabel 1 antara ujicoba 3 dan 4 . Nilai rata-rata ujicoba $3(14,85)$ lebih besar dari ujicoba $4(16,45)$. Setelah mendapatkan standar deviasi antara uji coba 3 dan 4 akan diperoleh standar deviasi gabungan 3 dan 4 . Kemudian digunakan untuk menghitung $\mathrm{t}_{34 \text { hitung }}$ diperoleh hasil 2,79 lebih besar dari $t$ tabel $(38,0,05)$ dengan derajat bebas 38 dengan tingkat kesalahan 5\% sebesar 2,021 . Perbandingan antara uji coba 3 dan 4 dihasilkan $\mathrm{t}_{\text {hitung }}$ lebih besar dari $\mathrm{t}_{\text {tabel }}$ modul filsafat bahasa layak dan efektif digunakan dalam pembelajaran khususnya uji coba 4.

Berdasarkan hasil eksperimen yang telah dilakukan untuk uji coba 1, 2, 3, dan 4 hasil $t_{\text {hitung }}$ untuk uji coba 1, 2, 3, dan 4 dan dibandingkan antara keduanya diperoleh hasil $t_{\text {hitung }}$ lebih besar dari $t_{\text {tabel }}$ dengan derajat bebas 38 dengan tingkat kesalahan sebesar 5\%. Uji coba secara terbatas hasil uji $\mathrm{t}$ menghasilkan $\mathrm{t}_{\text {hitung }}\left(\mathrm{t}_{12}=2,77, \mathrm{t}_{13}=\right.$ $7,89, \mathrm{t}_{14}=8,96, \mathrm{t}_{23}=2,88, \mathrm{t}_{24}=4,69 \mathrm{t}_{34}=2,79$ ) lebih besar dari $t_{\text {tabel }}$ dengan derajat bebas 38 (2,021). Kesimpulannya Ho diterima modul filsafat bahasa scientific berbasis nilai kearifan lokal dan filsafat bahasa kekinian layak digunakan untuk kegiatan pembelajaran pada mata kuliah filsafat bahasa di Jurusan Bahasa dan Sastra Indonesia STKIP PGRI Pacitan. Efektifitas modul memperlihatkan terjadinya peningkatan kompetensi mahasiswa terutama kompetensi menyimak, membaca, menulis dan berbicara.

\section{Tahap Uji Luas}

Uji coba pemakaian uji secara luas menggunakan eksperimen one group pretestpostest. Karakteristik modul telah sesuai dengan persyaratan dari teori pada modul yang baik, karena dalam modul terdapat instruksi, kemandirian, berdiri sendiri, dapat menyesuaikan diri, mudah digunakan (Ditjen Peningkatan Mutu, 2008: 2-3). Walaupun secara teoritis design modul telah layak digunakan namun perlu adanya uji secara luas untuk mengetehui kelayakan modul hasil pengembangan ini di Lambaga pendidikan tinggi lainnya. Untuk uji secara luas peneliti melakukan uji coba di STKIP Ponorogo untuk mengetahui kelayakan atau efektifitas modul "Filsafat Bahasa dalam Scientific Berbasis Nilai Kearifan Lokal" dan "filsafat bahasa kekinian" efektif dalam kegiatan pembelajaran filsafat bahasa.

Peneliti melakukan 3 kali uji coba untuk mendapatkan hasil kompetensi mahasiswa dengan mengerjakan evaluasi dalam setiap modul. Hasil dari evaluasi tersebut harus didiskusikan didepan kelas untuk melihat kompetensi berbicara mahasiswa. Walaupun dijawaban tertulis mahasiswa sederhana bahkan hanya beberapa kalimat dapat dikembangkan dengan baik pada saat diskusi di kelas. Berdasarkan nilai mahasiswa peneliti mendapatkan nilai rata-rata dari 20 mahasiswa yang terlibat dalam pembelajaran di kelas. Nilai rata-rata uji coba 4, 5, dan 6 dapat digunakan untuk memperoleh standar deviasi masing-masing dianalisis dengan uji $t$ adapun hasil uji t dapat dilihat dalam Tabel 2. 
Tabel 2. Data hasil uji coba luas dengan tingkat kesalahan 5\%

\begin{tabular}{lcccccc}
\hline Kegiatan & Rata-rata & Standar deviasi & Standar Deviasi & T Hitung & $\begin{array}{c}\text { Derajad Bebas } \\
(\mathbf{d b})\end{array}$ & $\begin{array}{c}\text { T } \\
\text { Tabel }\end{array}$ \\
\hline Uji coba 5 & 11,18 & 2,198 & & & & \\
Uji coba 6 & 13,45 & 2,987 & 2,622 & 2,766 & 38 & 2,021 \\
Uji coba 5 & 11,16 & 2,198 & & & & \\
Uji coba 7 & 15,35 & 2,212 & 2,046 & 6,481 & 38 & 2,021 \\
Uji coba 6 & 13,45 & 2,987 & & & & \\
Uji coba 7 & 15,35 & 2,212 & 2,628 & 2,288 & 38 & 2,021 \\
\hline
\end{tabular}

Berdasarkan tabel 2 kita bandingkan antara ujicoba 5 dan 6 , untuk nilai ratarata uji coba $6(13,45)$ lebih besar dari ujicoba $5(11,18)$. Pengujian signifikansi diperoleh $\mathrm{t}_{\text {hitung }}$ 2,77 lebih besar dari $\mathrm{t}_{\text {tabel }}$ 2,021 . Dengan demikian perbedaan hasil uji coba 5 dan 6 signifikan. Modul filsafat bahasa efektif digunakan karena dapat meningkatkan kompetensi pada uji coba 5 dan 6.

Berdasarkan tabel 2 di atas kita bandingkan antara ujicoba 5 dan 7 , untuk nilai rata-rata ujicoba $7(15,35)$ lebih besar dari ujicoba $5(11,18)$. Pengujian signifikansi diperoleh t hitung $(6,48)$ lebih besar dari $t$ tabel $(2,021)$. Dengan demikian perbedaan hasil ujicoba 5 dan 7 signifikan. Modul filsafat bahasa efektif digunakan karena dapat meningkatkan kompetensi mahasiswa.

Berdasarkan tabel 2 di atas kita bandingkan antara uji coba 6 dan 7, untuk nilai rata-rata uji coba $7(15,53)$ lebih besar dari uji coba $6(13,45)$. Pengujian signifikansi diperoleh thitung $(2,29)$ lebih besar dari t tabel $(2,021)$. Dengan demikian perbedaan hasil uji coba 6 dan 7 signifikan. Modul filsafat bahasa efektif digunakan karena dapat meningkatkan kompetensi mahasiswa.

Hasil uji t dalam kegiatan uji coba 5, 6, 7 dengan membandingkan hasil post test dan pre test untuk uji coba 5, 6, dan 7 untuk mendapatkan rata-rata nilai akhir mahasiswa dalam setiap uji coba. Hasil nilai rata-rata dibandingkan antara uji coba 5 dengan 6, uji coba 5 dengan uji coba
7, dan uji coba 6 dengan uji coba 8 untuk mencari standar deviasi perbandingan dari setiap dua perbandingan tersebut. Uji coba secara luas hasil uji $t$ menghasilkan $\mathrm{t}_{\text {hitung }}$ lebih besar $\left(\mathrm{t}_{56}=2,77, \mathrm{t}_{57}=6,48\right.$, dan $\left.t_{67}=2,29\right)$ lebih besar dari $t_{\text {tabel }}$ dengan derajat bebas 38 (2,021). Kesimpulannya Ho diterima modul filsafat bahasa scientific berbasis nilai kearifan lokal dan filsafat bahasa kekinian layak digunakan untuk kegiatan pembelajaran pada mata kuliah filsafat bahasa di Jurusan Bahasa dan Sastra Indonesia Sekolah Tinggi keguruan. Modul filsafat bahasa scientific dan filsafat bahasa kekinian dapat diproduk secara masal disesuaikan dengan kebutuhan di pasaran.

\section{SIMPULAN}

Penelitian pengembangan ini bertujuan untuk mengembangkan Modul "Filsafat bahasa dengan Scientific Berbasis Nilai Kearifan Lokal" dan 'Filsafat Bahasa Kekinian". Sejalan dengan tujuan tersebut desain penelitian yang digunakan adalah penelitian pengembangan sebagai berikut: (1) identifikasi masalah, (2) pengumpulan data, (3) desain produk, (4) validasi desain, (5) revisi desain, (6) ujicoba produk terbatas, (7) revisi produk, (8) uji coba pemakaian, (9) revisi produk, dan (10) produk masal.

Berdasarkan dari hasil respon angket mahasiswa terhadap modul filsafat bahasa scientific didapatkan respon mahasiswa $80,2 \%$. Berdasarkan hasil angket respon mahasiswa peneliti berusaha untuk me- 
refisi kembali modul filsafat bahasa tersebut. Adapun yang mendapatkan jawaban rendah sebagai berikut, modul belum disusun secara kronologis sehingga membuat mahasiswa untuk sulit dalam memahami materi filsafat bahasa. Selain itu modul kurang menarik karena tulisannya tidak begitu jelas sehingga akan menggurangi daya tarik mahasiswa untuk membacanya. Ejaannya terutama dalam kutipan masih banyak yang keliru dan penggunaan tanda miring pada hurus asing masih terlihat kesalahan penulis.

Peneliti melakukan proses refisi modul menjadi lebih menarik dengan judul "Filsafat Bahasa Scientific Berbasis Nilai Kearifan Lokal". Setelah proses refisi selesai peneliti melakukan uji validasi ahli dari Universitas Negeri Surakarta dan STKIP PGRI Ponorogo untuk menilai kelayakan modul yang peneliti kembangkan. Hasil validasi ahli modul mendapatkan skor $89 \%$ layak digunakan untuk pembelajaran. Adapun aspek penilaiannya meliputi: (1) struktur modul (cover, kata pengantar, daftar isi, kompetensi, kegiatan pembelajaran, organisasi penyajian, tampilan modul, keterkaitan antar materi); (2) organisasi penulisan materi (cakupan materi, kejelasan materi, keterkaitan materi dengan kompetensi, keterkaitan materi dengan konteks); dan (3) penggunaan bahasa sesuai dengan EYD.

Berdasarkan hasil validasi ahli peneliti membagi modul menjadi 2 yaitu; (1) filsafat bahasa scientific berbasis nilai kearifan lokal, dan (2) filsafat bahasa kekinian. Peneliti melakukan refisi berkaitan dengan penulisan tanda baca, kata asing yang harus dimiringkan, dan cara pengutipan.

Tahap selanjutnya peneliti melakukan uji terbatas dengan menggunakan metode eksperimen single one shot case study. Uji coba secara terbatas hasil uji $t$ menghasilkan $\mathrm{t}$ hitung $\left(\mathrm{t}_{12}=2,77, \mathrm{t}_{13}=7,89, \mathrm{t}_{14}=8,96\right.$, $\left.\mathrm{t}_{23}=2,88, \mathrm{t}_{24}=4,69 \mathrm{t}_{34}=2,79\right)$ lebih besar dari $\mathrm{t}_{\text {tabel }}$ dengan derajat bebas $38(2,021)$. Ke- simpulannya Ho diterima mengandung pengertian bahwa modul filsafat bahasa scientific berbasis nilai kearifan lokal dan filsafat bahasa kekinian layak digunakan untuk kegiatan pembelajaran pada mata kuliah filsafat bahasa di Jurusan Bahasa dan Sastra Indonesia.

Uji coba pemakaian uji secara luas menggunakan eksperimen one group pretest-postest. Uji coba secara luas hasil uji $\mathrm{t}$ menghasilkan $\mathrm{t}_{\text {hitung }}$ lebih besar $\left(\mathrm{t}_{56}=\right.$ $2,77, \mathrm{t}_{57}=6,48$, dan $\mathrm{t}_{67}=2,29$ ) lebih besar dari $t_{\text {tabel }(38,0,05)}$ sebesar 2,021. Kesimpulannya $\mathrm{H}_{\mathrm{o}}$ diterima mengandung arti bahwa modul filsafat bahasa scientific berbasis nilai kearifan lokal dan filsafat bahasa kekinian layak digunakan untuk kegiatan pembelajaran pada mata kuliah filsafat bahasa di Jurusan Bahasa dan Sastra Indonesia Perguruan Tinggi.

\section{UCAPAN TERIMA KASIH}

Ucapan terima kasih kepada Dirjen Dikti yang telah mendanai penelitian ini. Ucapan terima kasih kepada Ketua STKIP PGRI Pacitan dan LPPM STKIP PGRI Pacitan yang telah memfasilitasi penelitian ini.

\section{DAFTAR PUSTAKA}

Anwar, Ilham. 2010. Pengembangan Bahan Ajar. Bahan Kuliah Online. Direktori UPI. Bandung.

Daryanto. 2013. Menyusun Modul Bahan Ajar Untuk Persiapan Guru Dalam Mengajar. Malang: Gava Media.

Direktorat Tenaga Kependidikan, Dirjen peningkatan Mutu. 2008, Penulisan Modul. Pendidik dan Tenaga Kependidikan. Jakarta. Departemen Pendidikan Nasional.

Kamus Besar Bahasa Indonesia (Edisi Kedua). 1994. Jakarta: Balai pustaka.

Menteri Pendidikan dan Kebudayaan Republik Indonesia. 2013. Peraturan Menteri Pendidikan dan Kebudayaan Republik Indonesia nomor 73 tahun 2013 tentang Penerapan Kerangka Kualifikasi 
Nasional Indonesia (KKNI Pendidikan Tinggi. Jakarta Indonesia: Kementerian Pendidikan dan Kebudayaan Republik Indonesia.

Prastowo, Andi. 2014. Panduan Kreatif Membuat Bahan Ajar Inovatif. Yogyakarta: DIVA Press

Presiden Republik Indonesia. 2012. Peraturan Presiden RI No. 8 Tahun 2012 tentang Kerangka Kualifikasi Nasional Indonesia (KKNI). Jakarta, Indonesia. Sekretaris Negara

Santyasa, I Wayan. 2009. Metode Penelitian Pengembangan dan Teori Pengembangan Modul. Makalah disajikan dalam Pelatihan Bagi Para Guru TK, SD, SMP, SMA, dan SMK, Bali 12-14 Januari 2009. Singaraja: Universitas Pendidikan Ganesha.
Sudarwati, Ninik. 2013. Developing an Integrated Module on Entrepreneurship to Improve Ability in Making Business Plans. International Journal of Business, Humanities and Technology Vol. 3 No. 5; May 2013

Sugiyono. 2011. Metode Penelitian Kuantitatif Kualitatif dan RED. Bandung: Alfabeta

Sugiyono. 2010. Metode Penelitian Kuantitatif Kualitatif dan RED. Bandung: Alfabeta.

Suyatno, S. 2016. Revitalisasi Kearifan Lokal sebagai Upaya Penguatan Identitas. Artikel. Badan Pengembangan dan Pembinaan Bahasa. Kemendikbud.

Varelas, M and Ford M. 2009. The Scientific Method And Scientific Inquiry: Tensions In Teaching And Learning. USA: Wiley Inter Science. 